\title{
Sarcoidosis in an adult with cystic fibrosis
}

\section{STEVEN D RETTINGER, ELBERT P TRULOCK, BOBBIE MACKAY, HARVEY S AUERBACH}

\author{
From the Edward Mallinkrodt Department of Pediatrics, Division of Pulmonary Medicine, and the Department \\ of Medicine, Respiratory and Critical Care Division, Washington University School of Medicine, St Louis, \\ Missouri, USA
}

\begin{abstract}
Sarcoidosis in an adult patient with cystic fibrosis lung disease was diagnosed on the basis of pulmonary function and radiographic data. It should be considered in the differential diagnosis of new diffuse interstitial infiltrates or hilar adenopathy in a patient with cystic fibrosis; biopsy of lung, lymph node, or skin lesions and interleukin-2 receptor levels may help to obtain a diagnosis.
\end{abstract}

The diagnosis of coexistent pulmonary disease in the presence of chronic lung disease due to cystic fibrosis can be difficult. The clinician must remain vigilant for other causes of deteriorating lung function, however, as delay in diagnosis may result in inadequate treatment.

\section{Case report}

A 29 year old white man with cystic fibrosis was admitted to hospital because of deteriorating pulmonary function values and the appearance of a new interstitial infiltrate on the chest radiograph. Cystic fibrosis had been diagnosed when he was 13, with a sweat chloride concentration on pilocarpine iontophoresis' of $860 \mathrm{mmol} / \mathrm{l}$. At the ages of 13 and 22 years the patient was admitted to hospital because of dehydration but was otherwise generally healthy, having pancreatic enzyme replacement therapy.

At the age of 28 , seven months before admission to hospital, he had noted the onset of occasional episodes of chest tightness at rest, which were relieved with salbutamol from a metered dose inhaler. Physical examination showed nothing remarkable. A chest radiograph showed bilateral hilar enlargement, diffuse interstitial infiltrates, bronchiectasis localised to the right upper lobe, and hyperinflation. Pulmonary function tests (table: 21 January 1988) indicated a decline in the forced expiratory volume in one second $\left(F E V_{1}\right)$, vital capacity, and flow at $25-75 \%$ of vital capacity from previous measurements. A full blood count and differential count were within normal limits. Serological studies for Histoplasma capsulatum and Mycoplasma pneumoniae gave negative results. Serum IgE levels and human immunodeficiency virus titres were normal. The tuberculin skin test

Address for reprint requests: Dr Harvey S Auerbach, Department of Pediatrics, Washington University School of Medicine, 400 South Kingshighway Boulevard, St Louis, Missouri, USA 63110.

Accepted 9 May 1989 response was negative. Sputum cultures grew Pseudomonas aeruginosa. Intravenous tobramycin and ticarcillin, chest physiotherapy, and bronchodilators were given for 14 days with little clinical improvement.

One month after discharge the chest radiograph and pulmonary function tests (table: 17 February 1988) showed no improvement. Fibreoptic bronchoscopy disclosed no endobronchial lesions, and transbronchial lung biopsy was performed. This showed multiple non-necrotising granulomas. Special stains for acid fast and fungal organisms gave negative results, and no birefringent foreign particles were present. Cultures of bronchial washings were negative for mycobacteria and fungi. The serum calcium concentration was 2.4 (normal $2.25-2.75$ ) $\mathrm{mmol} / \mathrm{l}$, and serum angiotensin converting enzyme activity was 54 (normal 20-60) nmol $/ \mathrm{min} /$ $\mathrm{ml})$. A gallium-67 scan showed moderately increased uptake in both lungs with focal areas of increased activity in the left lung base and right perihilar region. The serum interleukin-2 receptor level was raised at $640 \mathrm{U} / \mathrm{ml}$ (normal $<477 \mathrm{U} / \mathrm{ml}^{2}$ ). On the basis of the radiographic pattern and histological findings the diagnosis of sarcoidosis was made (radiological stage II).

\section{Discussion}

We describe a patient with lung disease associated with cystic fibrosis and coincident sarcoidosis. A review of published reports brought to light only one report (of two cases) of sarcoidosis in the setting of cystic fibrosis. ${ }^{3}$ Though pulmonary function and radiographic data suggested the diagnosis of sarcoidosis in our patient, the diagnosis may be

Results of pulmonary function studies (\% predicted normal in parentheses) in a patient with sarcoidosis and cystic fibrosis

\begin{tabular}{|c|c|c|c|c|}
\hline & $\begin{array}{l}30 \text { June } \\
1987\end{array}$ & $\begin{array}{l}21 \mathrm{Jan} \\
1988\end{array}$ & $\begin{array}{l}17 \mathrm{Feb} \\
1988\end{array}$ & $\begin{array}{l}19 \text { April } \\
1988\end{array}$ \\
\hline $\begin{array}{l}\text { FEV }_{1}(1) \\
\text { FVC (1) } \\
\text { FEV }_{1} / \text { FVC (\%) } \\
\text { FEV }_{25-75}(1) \\
\text { TLC }(1) \\
\text { TLCO (mmol min }\end{array}$ & $\begin{array}{c}4 \cdot 92(112) \\
6 \cdot 33(120) \\
77(93) \\
4 \cdot 26(91) \\
7 \cdot 28(114)\end{array}$ & $\begin{array}{c}3.72(85) \\
5.69(108) \\
65(78) \\
2.07(45) \\
7.26(113)\end{array}$ & $\begin{array}{c}4 \cdot 22(96) \\
5 \cdot 83(111) \\
72(87) \\
2 \cdot 86(62) \\
\end{array}$ & $\begin{array}{c}3.92(90) \\
5.64(107) \\
69(83) \\
2.39(51) \\
\end{array}$ \\
\hline $\mathrm{kPa}^{-1} \mathbf{1}$ & - & $9.74(73)$ & - & - \\
\hline
\end{tabular}

FEV 1 -forced expiratory volume in one second; FVC-forced vital capacity; $\mathrm{FEV}_{25-75}$-volume expired during time interval between $0.25 \times$ FVC and $0.75 \times$ FVC; TLC - total lung capacity; TLCosingle breath transfer factor for carbon monoxide, corrected for haemoglobin concentration. 
elusive in patients with more advanced lung disease. The diagnosis may be made on the basis of pulmonary function values, chest radiographs, serum interleukin- 2 receptor levels, and biopsy specimens of lung, lymph node, or skin lesions. Sarcoidosis should be considered in the differential diagnosis of new diffuse pulmonary interstitial infiltrates or hilar adenopathy in patients with cystic fibrosis.

We thank Drs $\mathbf{N}$ Windsor and $\mathrm{E}$ Clinton Lawrence, Houston, Texas, for kindly measuring the interleukin-2 receptor level in our patient's serum.

\section{References}

1 Gibson LE, Cooke RE. A test for concentration of electrolytes sweat in cystic ofbrosis of the pancreas utilising pilocarpine inotophoresis. Pediatrics 1959;23:545-9.

2 Lawrence CE, Brousseau KP, Berger MB, Kurman CC, Marco L, Nelson DL. Elevated concentrations of soluble interleukin receptors in serum samples and bronchoalveolar lavage fluids in active sarcoidosis. Am Rev Respir Dis 1988;137:759-64.

3 Cooper TJ, Day AJ, Weller PH, Geddes DM. Sarcoidosis in two patients with cystic fibrosis: a fortuitous association? Thora $1987 ; 42: 818-20$ 